\title{
Environmental awareness of Protestant youth in Germany: Perspectives from an empirical exploration
}

\begin{tabular}{|c|c|}
\hline $\begin{array}{l}\text { Author: } \\
\text { Thomas Kroec }\end{array}$ & $k^{1,2}$ \\
\hline $\begin{array}{l}\text { Affiliations: } \\
{ }^{1} \text { Department } \\
\text { Development } \\
\text { Akademie für } \\
\text { Fühungskräfte } \\
\text { Gummersback }\end{array}$ & $\begin{array}{l}\text { or } \\
\text { Studies, } \\
\text { christliche } \\
\text {, Germany }\end{array}$ \\
\hline $\begin{array}{l}{ }^{2} \text { Department } \\
\text { Theology and } \\
\text { Studies, Facul } \\
\text { and Religion, } \\
\text { South Africa, } \\
\text { South Africa }\end{array}$ & $\begin{array}{l}\text { f Practical } \\
\text { Mission } \\
\text { y of Theology } \\
\text { Jniversity of } \\
\text { retoria, }\end{array}$ \\
\hline $\begin{array}{l}\text { Correspondin } \\
\text { Thomas Kroec } \\
\text { thomas.kroec }\end{array}$ & $\begin{array}{l}\text { g author: } \\
\text { k, } \\
\text { @acf.de }\end{array}$ \\
\hline $\begin{array}{l}\text { Dates: } \\
\text { Received: } 30 \text { I } \\
\text { Accepted: } 21 \\
\text { Published: } 27\end{array}$ & $\begin{array}{l}\text { Mar. } 2021 \\
\text { une } 2021 \\
\text { Aug. } 2021\end{array}$ \\
\hline $\begin{array}{l}\text { How to cite th } \\
\text { Kroeck, T., } 202 \\
\text { 'Environment } \\
\text { Protestant yol } \\
\text { Perspectives f } \\
\text { empirical expl } \\
\text { HTS Teologies } \\
\text { Theological St } \\
77(2), \text { a6638. } \\
\text { org/10.4102/ }\end{array}$ & $\begin{array}{l}\text { is article: } \\
1 \text {, } \\
\text { l awareness of } \\
\text { th in Germany: } \\
\text { om an } \\
\text { oration', } \\
\text { 'Studies/ } \\
\text { udies } \\
\text { https://doi. } \\
\text { its.v77i2.6638 }\end{array}$ \\
\hline $\begin{array}{l}\text { Copyright: } \\
\text { (C) 2021. The } \\
\text { Licensee: AOS } \\
\text { is licensed un } \\
\text { Creative Comr } \\
\text { Attribution Lio }\end{array}$ & $\begin{array}{l}\text { uthors. } \\
\text { S. This work } \\
\text { ler the } \\
\text { nons } \\
\text { ense. }\end{array}$ \\
\hline Read online: & \\
\hline 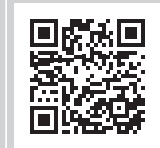 & $\begin{array}{l}\text { Scan this QR } \\
\text { code with your } \\
\text { smart phone or } \\
\text { mobile device } \\
\text { to read online. }\end{array}$ \\
\hline
\end{tabular}

Climate change and environmental degradation are pressing issues in the 21st century, which have also been addressed by Christian churches. Christian congregations are expected to provide an important impetus towards a more sustainable way of life. However, in Germany, empirical data on how Christian congregations and their members relate to this issue are scarce. This article presents the first results of a quantitative study on this topic, in particular, with regard to the differences between age groups. The focus is on the perceived importance of environmental conservation, environmental awareness, and the opportunities and obstacles for the engagement of Christians in creation care. An online survey which was conducted in 2020 yielded 736 complete responses from members of the Protestant churches, $19.7 \%$ of which were from young people under 30 years. Regarding the perceived importance of environmental conservation and environmental awareness, the results were largely consistent with the data of a representative study on environmental awareness in Germany. The young generation showed slightly lower values than the older ones. Members of Protestant church seem to be more willing to behave sustainably than the general public, with the under 30 years old being in particular concerned about food consumption. Motivational and subcultural opportunities for Christian conservation efforts were identified. Obstacles were based primarily on eschatological views and the fear that other mandates of the church may be neglected. Regarding obstacles, young respondents showed a stronger approval than the older generations.

Contribution: The article presents empirical evidence on the environmental awareness of Protestant Christians in Germany and identifies the opportunities and obstacles for their engagement in creation care.

Keywords: environmental awareness; creation care; youth; church; environmental theology; Germany.

\section{Introduction and theoretical framework}

In recent years, the issues of climate change and the destruction of ecosystems have received widespread attention. Young people contributed to this awareness in particular with the 'Fridays for Future' demonstrations. The awareness of these issues has become a topic of academic research. In Germany, the Federal Ministry of Environment has been conducting representative surveys on the environmental awareness of the population since 1996 and has developed specific questions and parameters for this purpose (BMU 2019:67f.). The views and behaviour of young people regarding environmental issues have also been addressed in the Shell youth study (Shell Deutschland 2020), the Sinus youth study (Calmbach, Flaig \& Edwards 2020) and by the Federal Ministry of Environment (BMU 2020).

The Christian churches have also been addressing the topic, specifically at the level of denominational leadership. Some examples are the Encyclical letter Laudato Si of Pope Francis (2015), the paper of the German evangelical churches on sustainable development (EKD 2015) and the 'Global Consultation on Creation Care and the Gospel' (Lausanne Movement 2012). As the Canadian sociologist Randolph Haluza-DeLay (2014) and the Catholic social ethicist Vogt (2010) explain, Christian congregations may provide important impetus towards a more sustainable way of life. Haluza-DeLay (2014) proposes a framework for evaluating the views of Christians regarding environmental issues, which will be used in this study.

Note: Special Collection: Youth, Faith, Climate Change and Environmental Consciousness: A Case for Sustainable Development, sub-edited by Jacques Beukes (University of Pretoria), Julianne Stork (Humboldt University, Berlin) and Ignatius Swart (University of the Western Cape). 
Although there are Christian initiatives like the environmental management of the Protestant and Roman Catholic mainline churches (www.kirum.org) or the nature conservation network, A Rocha (www.arocha.org), in Germany, the issue of creation care seems to receive little attention at the local congregational level. Whilst empirical data on how Christian congregations and their members relate to this issue are available in North America (e.g. Haluza-DeLay 2008, Peifer, Ecklund \& Fullerton 2014), they are scarce in Germanspeaking countries. In order to close this gap, a study was initiated by the section Development Studies of the Academy for Christian Leadership, ${ }^{1}$ with the intention to identify chances and obstacles for the engagement of Christians in creation care. In this article, the first results of this study are presented, especially with regard to differences between age groups.

\section{Research methods and design}

This study uses a quantitative approach and is based on an online survey conducted from the end of May to the beginning of October 2020. The topics covered in the survey were environmental awareness, characteristics of the Christian congregations, reasons for or against involvement in creation care, and demographic data. Some of the items were taken from the study of the Federal Ministry for Environment (BMU 2019).

To find participants, local congregations were approached directly and then the link to the survey was distributed through various networks. The responses came mainly from congregations of the mainline Protestant churches (EKD), Free Evangelical Churches (FeG) and the pietistic movement (Gnadauer Verband ${ }^{2}$ ). The collected data did not allow to identify individual respondents and the study was not expected to cause any harm to participants. In total, there were 736 complete responses from members of the Protestant churches that could be evaluated. The data were analysed using descriptive statistics.

Table 1 provides an overview of the characteristics of the sample. In this sample, $19.67 \%$ of the respondents were less than 30 years old, with an average age of 23.63 years. In the study of the Federal Ministry for Environment (BMU 2019:25), those below 30 years old are characterised as the 'global and digital generation' (GG). The other age groups are summarised in this article as older generations (OG) and had a mean age of 53.89 years. Women and men were equally represented in the sample. Almost $80 \%$ of the respondents had a high school diploma or a university degree. Eighty-five per cent of them lived in the western parts of Germany.

Most respondents described themselves as rather, or very strongly religious. It is noticeable that, on average, the younger participants assessed themselves as somewhat 1.Akademie für christliche Führungskräfte, Gummersbach, Germany (www.acf.de).

2.The Gnadauer Verband is an umbrella organisation of congregations, which emerged from a revival movement in the second half of the 19th century in Germany and Switzerland. They are independent, although most of their adherents are member of the mainline Protestant Churches. more religious than the older generations. About half of the respondents had an above average concern for creation care. To offset this bias, some presentations of the results will distinguish between respondents who rate their concern for conservation as lower than average, average, or higher than average. As the sample size for the global and digital generation (GG) would be too small, the cross effect of age and church affiliation will not be considered in this article.

\section{Results}

\section{Perceived importance of environmental conservation}

As in the representative study of the Federal Ministry for Environment (BMU 2019), participants were asked about their personal assessment of environmental quality (air, water, food, biodiversity), and on the importance of the environment and climate protection compared to other current issues.

Like in the BMU study (BMU 2019), the environmental quality was rated better in the immediate environment than in the whole of Germany and significantly better than worldwide (see Figure 1). On average, the respondents' ratings were higher than in the BMU study. Members of the global and digital generation (GG, up to 29 years) gave slightly higher ratings in most cases than the older generations.

With regard to the importance of environmental and climate protection as a social task, this topic was ranked second by the younger as well as the older generation. In the BMU studies of 2019, it ranked third (p. 17) and in the BMU 2020 study with 14-22 years old, it had the first rank (p. 16). Although the survey was conducted during the Covid-19 pandemic, the importance of the health system was not rated higher than in the BMU study (BMU 2019).

\section{Environmental awareness}

The questions on environmental awareness were also taken from the BMU (2019) study. It uses the following categories: (1) Environmental cognition, which concerns evaluations

TABLE 1: Characteristics of the sample in relation to church affiliation.

\begin{tabular}{llcccccc}
\hline Generation $\uparrow$ Church & $\boldsymbol{n}$ & $\mathbf{\%}$ & $\begin{array}{c}\text { Age } \\
\text { (years) }\end{array}$ & $\begin{array}{c}\text { \% } \\
\text { Female }\end{array}$ & Religiosity* & $\begin{array}{c}\text { Environment } \\
\text { concern }\end{array}$ \\
\hline GG & EKD & 28 & 19 & 21.71 & 46 & 3.15 & 2.41 \\
& FEG & 44 & 31 & 24.27 & 59 & 3.43 & 2.19 \\
& Gnadau & 52 & 36 & 24.17 & 62 & 3.69 & 2.40 \\
& Other & 20 & 14 & 23.45 & 40 & 3.28 & 2.38 \\
& Total GG & 144 & 100 & 23.63 & 55 & 3.45 & 2.34 \\
OG & EKD & 148 & 25 & 56.77 & 53 & 3.08 & 2.54 \\
& FEG & 164 & 28 & 53.51 & 46 & 3.35 & 2.32 \\
& Gnadau & 185 & 31 & 52.09 & 45 & 3.50 & 2.26 \\
& Other & 95 & 16 & 53.60 & 59 & 3.47 & 2.39 \\
& Total OG & 592 & 100 & 53.89 & 47 & 3.35 & 2.37 \\
\hline
\end{tabular}

$\dagger, \mathrm{GG}$, global and digital generation (below 30 years), $\mathrm{OG}=$ older generations.

$\$$, Self-assessment of religiosity: 1 = not religious, 2 = little religious, $3=$ rather strongly religious, 4 = very strongly religious.

ๆ, Self-assessment of environmental concern in relation to the majority of the congregation: 1 = below average, 2 = average, 3 = above average. 
of this subject, (2) Environmental affect, related to positive and negative concern and (3) Environmental action, as concrete behaviour (BMU 2019:68). The results of the individual items were converted to a scale from 0 (low) to 10 (high).

As Figure 2 shows, the results were comparable to those of the BMU study. The respondents who rated their interest in protecting the environment as average were slightly lower in environmental cognition and affect and slightly higher in action than in the BMU study. Comparing the generations, environmental awareness seems to be somewhat less pronounced amongst the younger generation (GG) than amongst the older ones. With regard to congregational affiliation, members of the Protestant mainline church (EKD) had somewhat higher values. This is particularly clear amongst those with a below-average interest in environmental issues, whilst there were hardly any differences amongst those for whom these concerns are important.

As with the summary scores, there were similar trends for most of the individual items as in the BMU study (2019).
However, a few deviations should be noted. Regarding environmental cognition, the importance of the environment for a good life was rated lower by the younger generation (see Table 2).

There are also deviations in the environmental affect with regard to the statements 'I get annoyed when others want to tell me that I should live in an environmentally conscious way' and 'The environmental problem is greatly exaggerated by many environmentalists', for which there was less agreement than in the BMU study (see Table 2). This may indicate that members of the Protestant congregations are more open to behavioural change than the average German population. There were no pronounced differences between the generations in this regard.

In terms of environmental behaviour, it is noticeable that meat consumption was reported as being less frequent than in the BMU study (see Table 3). Fifty-five per cent of the younger generation stated that they rarely eat meat. Compared to the BMU study (2019), our data also revealed a somewhat stronger tendency to buy food from controlled organic cultivation and to support creation care with

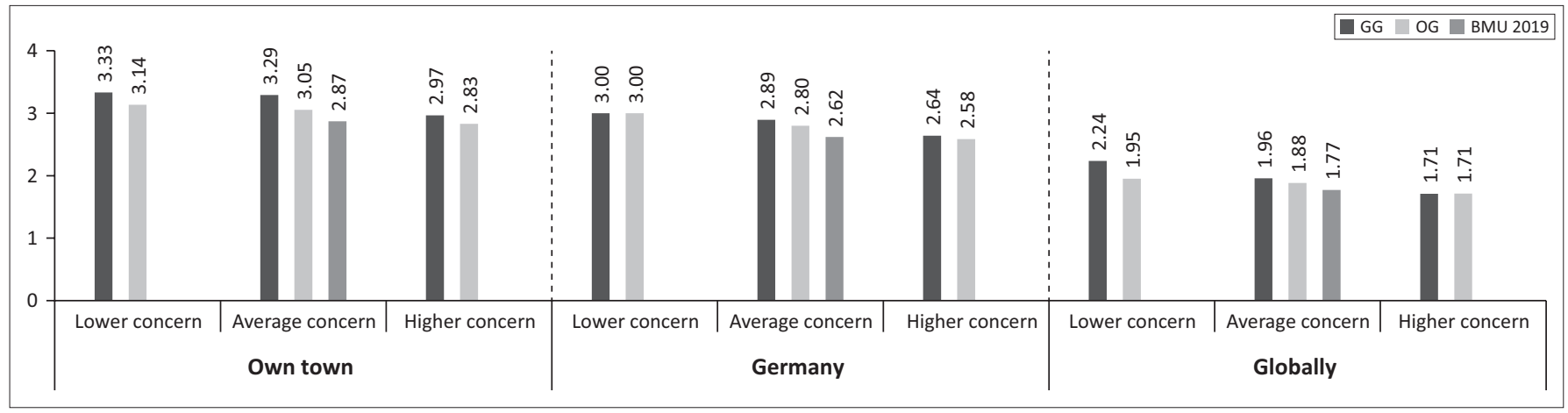

Source: Author's own data and BMU, 2019, Umweltbewusstsein in Deutschland 2018: Ergebnisse einer reprösentativen Bevölkerungsumfrage, Bundesministerium für Umwelt, Naturschutz und nukleare Sicherheit, Berlin.

FIGURE 1: Perception of environmental quality ( $1=$ very poor, $4=$ very good $)$ by age group $(\mathrm{GG}=$ under 30 years, OG = 30 years and above) and concern for environmental protection.

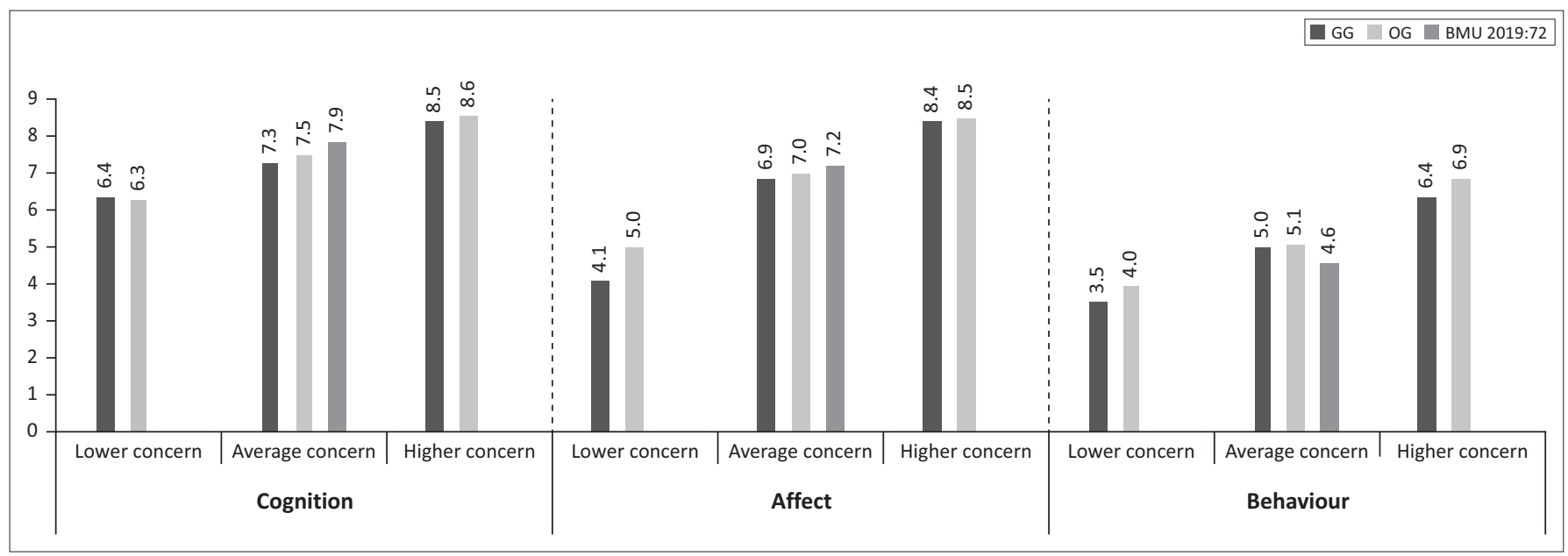

Source: Author's own data and BMU, 2019, Umweltbewusstsein in Deutschland 2018: Ergebnisse einer repräsentativen Bevölkerungsumfrage, Bundesministerium für Umwelt, Naturschutz und nukleare Sicherheit, Berlin.

FIGURE 2: Environmental awareness (range 0-10) by age groups ( $\mathrm{GG}=$ under 30 years, $\mathrm{OG}=30$ years and above) and concern for environmental protection (lower, average or higher concern). 
TABLE 2: Consent with selected items of environmental awareness by age group.

\begin{tabular}{|c|c|c|c|c|}
\hline Statements & Age group & Agree $(\%)$ & Disagree (\%) & n.a. (\%) \\
\hline \multirow{3}{*}{$\begin{array}{l}\text { Other things are } \\
\text { important for a good life } \\
\text { than the environment } \\
\text { and nature. }\end{array}$} & GG & 35 & 61 & 4 \\
\hline & OG & 28 & 70 & 2 \\
\hline & Total & 30 & 68 & 2 \\
\hline \multirow{5}{*}{$\begin{array}{l}\text { More environmental } \\
\text { protection means more } \\
\text { quality of life and health } \\
\text { for all. }\end{array}$} & BMU 2019 & 17 & 81 & 2 \\
\hline & GG & 82 & 17 & 1 \\
\hline & OG & 89 & 9 & 2 \\
\hline & Total & 88 & 10 & 2 \\
\hline & BMU 2019 & 90 & 8 & 2 \\
\hline \multirow{3}{*}{$\begin{array}{l}\text { The environmental issue } \\
\text { is greatly exaggerated by } \\
\text { many environmentalists. }\end{array}$} & GG & 19 & 71 & 10 \\
\hline & OG & 24 & 73 & 3 \\
\hline & Total & 23 & 73 & 4 \\
\hline & BMU 2019 & 36 & 61 & 3 \\
\hline 䎹 I get annoyed when & GG & 30 & 68 & 1 \\
\hline $\begin{array}{l}\text { others want to tell me } \\
\text { that I should live in an }\end{array}$ & OG & 28 & 70 & 2 \\
\hline environmentally & Total & 29 & 69 & 2 \\
\hline & BMU 2019 & 61 & 37 & 2 \\
\hline
\end{tabular}

Source: Author's own data and BMU, 2019, Umweltbewusstsein in Deutschland 2018: Ergebnisse einer repräsentativen Bevölkerungsumfrage, Bundesministerium für Umwelt, Naturschutz und nukleare Sicherheit, Berlin.

$\mathrm{GG}$, under 30 years, $\mathrm{OG}, 30$ years and above, n.a., no answer.

TABLE 3: Consumption patterns by age group.

\begin{tabular}{llcccc}
\hline Behaviour & Age group & $\begin{array}{c}\text { Mostly } \\
(\mathbf{\%})\end{array}$ & $\begin{array}{c}\text { Sometimes } \\
(\mathbf{\%})\end{array}$ & $\begin{array}{c}\text { Rarely } \\
(\mathbf{\%})\end{array}$ & $\begin{array}{c}\text { n.a. } \\
\mathbf{( \% )}\end{array}$ \\
\hline I eat meat at the main & GG & 12 & 33 & 55 & 0 \\
meals. & OG & 8 & 53 & 39 & 0 \\
& Total & 9 & 48 & 43 & 0 \\
& BMU 2019 & 19 & 56 & 24 & 1 \\
$\begin{array}{l}\text { I buy food from } \\
\text { controlled }\end{array}$ & GG & 34 & 44 & 22 & 0 \\
organic farming. & OG & 31 & 53 & 16 & 0 \\
& Total & 32 & 51 & 17 & 0 \\
& BMU 2019 & 20 & 54 & 25 & 1 \\
\hline
\end{tabular}

Source: Author's own data and BMU, 2019, Umweltbewusstsein in Deutschland 2018: Ergebnisse einer repräsentativen Bevölkerungsumfrage, Bundesministerium für Umwelt, Naturschutz und nukleare Sicherheit, Berlin.

GG, under 30 years; OG, 30 years and above, n.a., no answer.

donations and active engagement. Regarding the last two aspects, values for the younger generation were somewhat lower than for the older ones.

Overall, the respondents from the younger generation were not characterised by a higher environmental awareness than the older participants. They rated the environmental quality more positively and showed slightly lower values for environmental cognition, affect and behaviour compared to the older generations.

\section{Opportunities and obstacles for the engagement of Christians in creation care}

The question of whether Christians and Christian congregations should be more involved in creation care was affirmed by $85 \%$ of the respondents. There were no significant differences between the younger and the older generations.

Open questions as well as Likert-type scales $^{3}$ were used to investigate reasons for or against the commitment to

3.Likert type scales are a commonly used tool for measuring personal attitudes in survey research.
TABLE 4: Reasons for or against engagement of Christians and churches in creation care by age group.

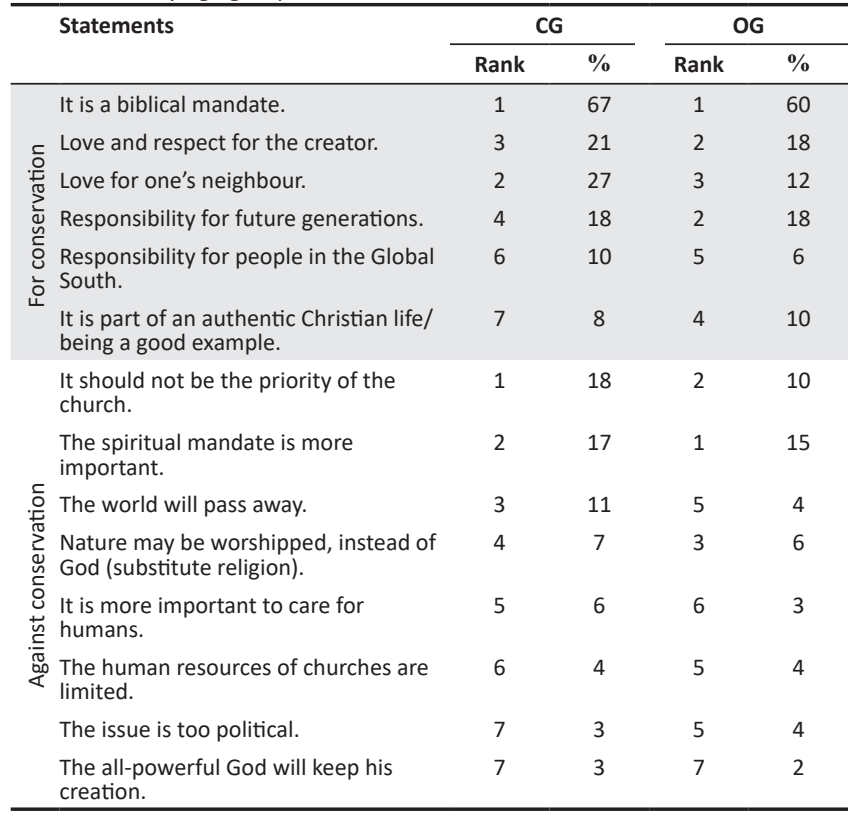

Open question, rank and frequency of mentioning, $\mathrm{GG}$, up to 29 years, $\mathrm{OG}, 30$ years and above.

creation care. A selection of reasons given to open questions are shown in Table 4.

\section{Opportunities}

In discussing the reasons for or against engagement of Christians and churches in creation care, the categories proposed by Haluza-DeLay were used. Regarding the opportunities for faith-based conservation, he sees three clusters: motivational, subcultural, and public theological (Haluza-DeLay 2008:76).

Motivational opportunities are understood as 'dimensions that potentially increase the effectiveness of environmental awareness because of the faith-based commitment' (HaluzaDeLay 2008:77). The care for creation, being in line with the biblical mandate in Genesis 2:15 was the top reason for engaging in creation care, followed by love and respect for the creator and love for one's neighbour (see Table 4). All three reasons were stated more often by members of the younger generation. Whilst all age groups expressed the responsibility for future generations equally, the younger respondents showed more concern for people in the countries of the Global South.

Regarding the relationship to other creatures, $69 \%$ of those under 30 years of age agreed that animals, plants and inanimate nature are our fellow creatures with whom we are more connected than separated', whilst in the older generations $76 \%$ approved this. There was also a difference between the denominations: $81 \%$ of EKD members with average concern for conservation agreed for members of FeG $(68 \%)$ and Gnadau congregations (72\%), this was lower.

Subcultural opportunities are 'social practices of congregations that lead to more effective learning occasions' (Haluza-DeLay 
2008:76). Twelve per cent of the respondents in a subsample of congregations with at least five respondents stated that the topic of creation care is addressed in sermons. However, there seems to be a distinct difference between the denominations. Whilst in this subsample, $19 \%$ of members of FeG and 17\% of Gnadauer congregations said that creation care was not a topic covered in their churches, only 1\% of EKD members said so. As shown in Table 2, members of Protestant churches in Germany object much less to being told to live in an environmentally conscious way than the German population in general, and about $90 \%$ of all respondents agreed that Christian congregations should motivate their members to work for the integrity of creation.

Public-Theological Opportunities are related to the way the churches 'constructively engage the public discourse within a pluralist society' (Haluza-DeLay 2008:77). The majority of respondents (90\%) agreed that churches should promote their values more strongly in the public and the political arena.

\section{Obstacles}

Haluza-DeLay distinguishes four primary clusters of obstacles to faith-based environmental engagement: paradigmatic, applicability, critical, and conviction (2008:74).

Paradigmatic obstacles are understood by Haluza-DeLay as 'elements of theological beliefs or worldviews that disable attention to environmental concerns' (p. 74). The following items are part of this cluster: The danger of idolising nature instead of honouring the Creator (conservation as substitute religion), the eschatological view that the world will pass away, and the opinion that an all-powerful God will not allow his creation to be destroyed by humans. Eschatology and the fear of nature being worshipped were the main points in this study. The younger generation agreed in particular that the world will pass away (see Tables 4 and 5). These views were less common in the Protestant mainline

TABLE 5: Approval of obstacles to creation care.

\begin{tabular}{|c|c|c|c|c|}
\hline Statements & $\begin{array}{l}\text { Age } \\
\text { group }\end{array}$ & $\begin{array}{c}\text { Agree } \\
(\%)\end{array}$ & $\begin{array}{l}\text { Disagree } \\
(\%)\end{array}$ & $\begin{array}{l}\text { n.a. } \\
(\%)\end{array}$ \\
\hline \multirow{2}{*}{$\begin{array}{l}\text { Because the world will pass away, it } \\
\text { is more important to work for } \\
\text { eternal causes than for the } \\
\text { protection of nature. }\end{array}$} & GG & 31 & 67 & 2 \\
\hline & OG & 25 & 72 & 4 \\
\hline \multirow{2}{*}{$\begin{array}{l}\text { Because God is all-powerful, he will } \\
\text { not let his creation be destroyed by } \\
\text { humans. }\end{array}$} & GG & 15 & 73 & 12 \\
\hline & OG & 20 & 71 & 9 \\
\hline \multirow{2}{*}{$\begin{array}{l}\text { Conservationists often idolise nature } \\
\text { instead of honouring the Creator. }\end{array}$} & GG & 50 & 32 & 18 \\
\hline & OG & 51 & 39 & 10 \\
\hline \multirow{2}{*}{$\begin{array}{l}\text { It is more important to care for } \\
\text { people in need than to } \\
\text { preserve creation. }\end{array}$} & GG & 60 & 22 & 18 \\
\hline & OG & 40 & 43 & 18 \\
\hline \multirow{2}{*}{$\begin{array}{l}\text { Our lifestyles and economy are } \\
\text { characterised by structures and } \\
\text { values that do not match to God's } \\
\text { ideas of a flourishing life. }\end{array}$} & GG & 73 & 13 & 14 \\
\hline & OG & 77 & 14 & 8 \\
\hline \multirow{2}{*}{$\begin{array}{l}\text { The lifestyles and attitudes of } \\
\text { Christians are influenced more by } \\
\text { their environment and advertising } \\
\text { than by biblical values. }\end{array}$} & GG & 48 & 40 & 12 \\
\hline & OG & 51 & 38 & 10 \\
\hline \multirow{2}{*}{$\begin{array}{l}\text { God has placed humans above the } \\
\text { rest of creation to dominate it and } \\
\text { use it for their own needs. }\end{array}$} & GG & 58 & 39 & 3 \\
\hline & OG & 47 & 48 & 6 \\
\hline
\end{tabular}

$\mathrm{GG}$, under 30 years, $\mathrm{OG}, 30$ years and above, n.a., no answer. churches (EKD). The argument of God's omnipotence did not play a major role in this study (see Tables 4 and 5).

Applicability obstacles are concerned with the appropriate amount of attention given to environmental concerns' (Haluza-DeLay 2008:75). The argument that other tasks of the congregation should not be neglected because of creation care was a major concern and was emphasised especially by the younger generation (see Table 4) and the members of the FeG and Gnadau congregations (20\% and 15\% approval compared to $2 \%$ for EKD members with average concern for creation care). It was specifically pointed out that spiritual concerns should not be neglected (see Table 4) and that helping people in need was more important than caring for creation (see Table 5).

Critical obstacles are understood as 'those that result from underanalysis of societal and cultural factors that affect the human-earth relationship' (Haluza-DeLay 2008:75). Most respondents agreed that the society and the lifestyles of Christians are influenced by non-biblical values (see Table 5). The approval was slightly higher from the older generations. There was not much difference in this aspect between the denominations. Haluza-DeLay (2008:75) considers viewing the environment mainly as a resource for human utilisation as a part of the Western culture. About half of the respondents agreed that God has placed humans above the rest of creation to dominate it and use it for their own needs. This value was again higher for the younger generation (see Table 5). Members of EKD churches showed less agreement on this statement.

\section{Discussion}

This study investigated the environmental awareness and views on creation care of the members of Protestant churches in Germany, most of whom described themselves as rather, or very strongly religious. Although the sample of this study was not representative and did not include all Protestant denominations, in many cases, the data were consistent with the results of the representative study on environmental awareness in Germany (BMU 2019). The respondents ranked environmental and climate issues similarly important, but their perception of environmental quality was slightly higher (see Figure 1). The high importance of environment and climate issues is also in line with the Shell study with 12 to 25-year-old Germans (Shell Deutschland 2020:56). The Sinus study of German teenagers showed that this concern is shared by young people from all social milieus (Calmbach et al. 2020:405f., 452).

Environmental cognition and affect were slightly lower than of the average German (see Figure 2). These differences are a little more pronounced in the younger generation. It seems that young Protestant Christians in Germany do not see the importance of an intact environment for their well-being as strongly as older generations (see Table 2). However, the participants of this study scored higher values in environmental behaviour (see Figure 2). The younger 
generation seems to be, particularly, more concerned about sustainable food consumption (see Table 3). The value for meat consumption (see Table 3 ) is close to the value of the BMU youth study for idealistic youth of $49 \%$ who prefer a predominantly vegetarian or vegan diet (BMU 2020:13). According to the Sinus categories, ${ }^{4}$ in particular young people from postmaterial and expeditive milieus are into vegetarian or vegan food and fair trade products (Calmbach et al. 2020:553). The doubts about the importance of economic growth, which BMU found for idealistic youth (BMU 2020:13) and also Calmbach et al. (2020:567), were also seen amongst the highly religious youth in our study. A striking difference is the much higher willingness of church members to consider a more sustainable lifestyle as shown in Table 2.

The majority of the respondents affirmed that Christians should be involved in creation care. However, the faith-based opportunities and obstacles for conservation mentioned by the respondents seem to keep in balance. As strong motivational opportunities, the biblical mandate in Genesis 2:15, respect and love for God the creator, and the commandment to love one's neighbour were identified (see Table 4). On the other hand, the data reveal that paradigmatic obstacles, especially, eschatology and the fear of nature worship (see Tables 4 and 5) restrict the engagement. In contrast to the results of a study in evangelical congregations in the USA (Peifer et al. 2014), the argument of God's omnipotence did not play a major role (see Table 5).

Interestingly, the younger generation showed stronger approval both for opportunities as well as for obstacles. This indicates that highly religious young people may have more clear-cut theological views compared to more mature Christians. On the practical side, there was a higher willingness for changes to the lifestyle and subcultural opportunities of discussing environmental issues in church, but creation care is also seen as competition for spiritual concerns (applicability obstacles). The later view is quite common for young people (see Tables 4 and 5). The younger respondents seem to be close to the 'idealistic youth' characterised by BMU (2020:12); however, they may focus their efforts on the church, rather than on protecting the environment.

As mentioned above, the study was not representative and covered only a limited section of the denominational spectrum of churches in Germany. Nevertheless, the research offers first insights into a topic, which has been little researched so far. It is planned as a next step to validate and deepen the results of the quantitative survey with qualitative interviews in various congregations.

\section{Conclusion}

Whilst this study primarily provides some insight into the environmental views in Protestant churches in Germany, it also offers some hints on how the engagement of churches in these issues could be strengthened. I see three areas for action: theological reflection, the incorporation of creation care in the activities of the congregation, and creative ways to communicate the concern for creation. For theological reflections, the dualism between the spiritual realm and nature, as well as eschatological stereotypes should be discussed and questioned. For the work in Christian congregations, the perceived competition between activities related to creation care and spiritual concerns need to be addressed. Creation care could be considered a form of diakonia, which is a genuine dimension of Christian life and service. Activities related to nature may stimulate the spiritual experiences of church members and can be a bridge to engage with other members of the local communities. Opportunities to communicate the concern for creation can be found in regular church activities such as worship services, small groups and clubs for children and teenagers. This aspect can enrich the spiritual lives of the participants and make Christian faith more tangible and practical. The results indicate the opportunity and need to encourage young Christians to reflect on these issues. For children and teenagers, Christian scouting can offer a framework for such activities, whilst organisations like the Christian conservation network 'A Rocha may provide opportunities for youth and adults.

\section{Acknowledgements Competing interests}

The author declares that he has no financial or personal relationships that may have inappropriately influenced him in writing this article.

\section{Author's contributions}

T.K. is the sole author of this research article.

\section{Ethical considerations}

This article followed all ethical standards for research, in particular, regarding anonymity and did not cause any harm to participants.

\section{Funding information}

This research received no specific grant from any funding agency in the public, commercial or not-for-profit sectors.

\section{Data availability}

The data are available on request.

\section{Disclaimer}

The views and opinions expressed in this article are those of the author and do not necessarily reflect the official policy or position of any affiliated agency of the author.

\section{References}

BMU, 2019, Umweltbewusstsein in Deutschland 2018: Ergebnisse einer repräsentativen Bevölkerungsumfrage, Bundesministerium für Umwelt, Naturschutz und nukleare Sicherheit, Berlin. 
BMU, 2020, Zukunft? Jugend fragen!: Umwelt, Klima, Politik, Engagement - Was junge Menschen bewegt, Bundesministerium für Umwelt, Naturschutz und junge Menschen bewegt,
nukleare Sicherheit, Berlin.

Calmbach, M., Flaig, B. \& Edwards, J., 2020, Wie ticken Jugendliche? 2020 Lebenswelten von Jugendlichen im Alter von 14 bis 17 Jahren in Deutschland, bpb, Bonn.

EKD, 2015, "... damit sie das Leben und volle Genüge haben sollen«: Ein Beitrag zur Debatte über neue Leitbilder für eine zukunftsfähige Entwicklung, EKD Texte 122, Evang. Kirche in Deutschland (EKD), Hannover, viewed 10 January 2021, from https://www.ekd.de/ekdtext_122 leitbilder.htm.

Francis, 2015, Encyclical letter Laudato Si - On care for our common house, Rome viewed 19 January 2021, from http://w2.vatican.va/content/dam/francesco/pdf/ encyclicals/documents/papa-francesco_20150524_enciclica-laudato-si_en.pdf.

Haluza-DeLay, R., 2008, 'Churches engaging the environment: An autoethnography of obstacles and opportunities', Research in Human Ecology 15(1), 71-81.
Haluza-DeLay, R., 2014, 'Religion and climate change: Varieties in viewpoints and practices', WIRES Climate Change 5(2), 261-279. https://doi.org/10.1002/ wcc. 268

Lausanne Movement, 2012, Lausanne global consultation on creation care and the Gospel: Jamaica call to action, St Ann, Jamaica, viewed 19 January 2021, from https://www.lausanne.org/content/statement/creation-care-call-to-action.

Peifer, J.L., Ecklund, E.H. \& Fullerton, C., 2014, 'How evangelicals from two churches in the American Southwest Frame their relationship with the environment', Review of Religious Research 56(3), 373-397. https://doi.org/10.1007/s13644014-0153-6

Shell Deutschland, 2020, Jugend 2019: Eine Generation meldet sich zu Wort, bpb Bonn.

Vogt, M., 2010, Worin besteht die theologische Kompetenz im Umweltdiskurs? Überlegungen aus katholischer Sicht, 14, Internationaler Renovabis-Kongress, In Verantwortung für die Schöpfung, Freising. 